\title{
Kemampuan Komunikasi Matematis dalam Mengubah Soal Cerita menjadi Model Matematika pada Siswa Kelas VIII MTs Darussalam Kademangan Blitar
}

\author{
Faudjiah Nur Khaini ${ }^{1}$ \\ ${ }^{1}$ Institut Agama Islam Negeri Tulungagung \\ Email: 1fauziahkhaini@gmail.com
}

\section{Tersedia Online di}

http://www.jurnal.unublitar.ac.id/ index.php/briliant

\begin{tabular}{l}
\hline Sejarah Artikel \\
\hline Diterima pada 2 November 2017 \\
Disetuji pada 2 November 2017 \\
Dipublikasikan pada 13 \\
November 2017 Hal. $459-469$ \\
\hline
\end{tabular}

Kata Kunci:

Pembelajaran, Komunikasi

matematis, Soal cerita,

\section{DOI:}

http://dx.doi.org/10.28926/briliant .$v 2 \mathrm{i} 4.109$

\begin{abstract}
Abstrak: Tujuan penelitian dalam skripsi ini adalah (1) Mendeskripsikan kemampuan komunikasi matematis siswa berkemampuan tinggi di kelas VIII MTs Darussalam Kademangan Blitar. (2) Mendeskripsikan kemampuan komunikasi matematis siswa berkemampuan sedang di kelas VIII MTs Darussalam Kademangan Blitar. (3) Mendeskripsikan kemampuan komunikasi matematis siswa berkemampuan rendah di kelas VIII MTs Darussalam Kademangan Blitar. Pendekatan dalam penelitian ini menggunakan penelitian kualitatif. Teknik pengumpulan data yang digunakan adalah tes, wawancara, dan dokumentasi. Hasil penelitian menunjukkan siswa mampu menggunakan variabel untuk memisalkan apa yang diketahui dalam soal cerita, siswa mampu mengubah bahasa matematika menjadi model matematika, dan siswa mampu merefleksikan bahasa matematika yang terdapat dalam soal cerita.
\end{abstract}

Kegiatan pembelajaran merupakan proses komunikasi untuk menyampaikan pesan dari pendidik kepada peserta didik, bertujuan agar pesan yang disampaikan oleh peserta didik dapat diterima baik dan berpengaruh terhadap pemahaman serta terbentuknya perubahan tingkah laku (Lanani, 2013:13). Pada proses komunikasi, terdapat beberapa komponen yang merupakan syarat terjadinya komunikasi. Komponen-komponen tersebut adalah komunikator, pesan, dan komunikan (Effendy, 2004:6). Pada kegiatan pembelajaran, pendidik bertugas sebagai komunikator, peserta didik bertugas sebagai komunikan, dan pesan yang disampaikan oleh pendidik adalah materi yang sedang diajarkan. Pendidik saling bertatap muka dan saling berhadapan dengan peserta didik. Sehingga materi dapat disampaikan dengan maksimal.

Pendidik sebagai komunikator ketika menyampaikan materi sebaiknya menggunakan ucapan yang lemah lembut sehingga mudah diingat oleh komunikan yang tidak lain adalah peserta didik. Penjelasan tersebut sesuai dengan firman Allah SWT dalam QS. Thaahaa ayat 44, yang berbunyi:

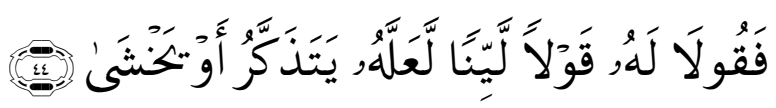

Artinya: “Maka berbicaralah kamu berdua kepadanya (Fir'aun) dengan kata-kata yang lemah lembut, mudah-mudahan dia sadar atau takut. 
Peserta didik ketika melakukan komunikasi tidak hanya berkomunikasi dengan pendidik saja. Tetapi peserta didik harus mampu mengkomunikasikan atau mengekspresikan ide-ide yang mereka peroleh dalam mata pelajaran tersebut. Mata pelajaran yang cenderung menggunakan kemampuan komunikasi adalah mata pelajaran matematika. Pada pembelajaran matematika, peserta didik diberikan penjelasan berupa materi. Sehingga kegiatan yang dilakukan oleh peserta didik hanya mendengarkan dan kemudian mengerjakan soal yang diberikan oleh pendidik. Proses aktivitas ini mengakibatkan terjadinya penghafalan prosedur atau konsep, apabila dihadapkan terhadap permasalahan yang tidak rutin atau kompleks maka peserta didik cenderung tidak dapat menyelesaikan masalah (Anisa, 2014). Masalah kompleks yang sering dihadapi peserta didik adalah ketika mereka mengerjakan soal cerita. Peserta didik merasa kesulitan ketika mengerjakan soal matematika yang diberikan oleh pendidik terutama soal cerita.

Salah satu alasan mengapa peserta didik merasa kesulitan dalam menyelesaikan soal matematika adalah peserta didik masih menganggap matematika itu sulit. Sehingga peserta didik selalu merasa takut ketika akan memulai pembelajaran matematika. Padahal pelajaran matematika sangat penting dalam kehidupan. Misalnya saat peserta didik mendapatkan materi aritmetika sosial. Peserta didik diajarkan untuk menghitung besar laba, rugi, harga jual, dan harga beli yang akan membantu peserta didik jika nantinya akan melakukan kegiatan jual beli. Sehingga dengan adanya pelajaran matematika, peserta didik tidak merasa kebingungan jika menjumpai penerapan konsep matematika dalam kehidupan. Pada penerapan konsep matematika yang dipelajari, didukung oleh kemampuan penalaran dan komunikasi yang relevan (Muzayanah \& Nugraheni: 287).

Kemampuan komunikasi matematis yang dimaksud adalah kemampuan untuk menyampaikan atau mengungkapkan ide, gagasan, alasan matematis kepada orang lain menggunakan bahasa matematika secara lisan maupun tertulis yang berupa simbol, gambar, grafik maupun bentuk aljabar (Yunianto \& Jailani, 2014:33). Matematika memiliki peran sebagai bahasa simbolik yang memungkinkan terwujudnya komunikasi yang cermat dan tepat (Ag \& Fathani, 2008:49). Peserta didik yang mempunyai kemampuan komunikasi matematis dapat dilihat dari cara mereka menyampaikan ide, gagasan, atau mengekspresikan bahasa matematika. Bahasa matematika yang dimaksud berupa simbol, gambar, grafik maupun bentuk aljabar sesuai dengan apa yang pendidik perintahkan. Pada pembelajaran matematika diperlukan komunikasi yang baik secara langsung ataupun tidak langsung yang dilakukan oleh pendidik dan peserta didik, sehingga proses pembelajaran berjalan dengan lancar.

Proses pembelajaran matematika juga terjadi proses berpikir, karena seseorang dikatakan berpikir apabila orang tersebut melakukan kegiatan mental dan orang yang belajar matematika pastinya melakukan kegiatan mental (Ag \& Fathani, 2008:49). Proses dalam belajar matematika juga membutuhkan kemampuan komunikasi. Komunikasi yang dilakukan oleh pendidik dan peserta didik ataupun komunikasi dalam mengekspresikan bahasa matematika yang berupa simbol, gambar, grafik, maupun bentuk aljabar. Sehingga dapat mempermudah peserta didik untuk menyelesaikan suatu masalah yang diberikan oleh pendidik. Kemampuan komunikasi harus dimiliki oleh setiap peserta didik, 
khususnya peserta didik Indonesia. Agar peserta didik tidak mengalami kesulitan dalam pembelajaran matematika. Tetapi, faktanya kemampuan komunikasi matematis di Indonesia masih rendah.

Alasan mengapa kemampuan komunikasi matematis di Indonesia masih rendah adalah menurut hasil penelitian Tim Pusat Penataran Guru Matematika mengungkapkan bahwa di beberapa wilayah Indonesia yang berbeda, sebagian besar peserta didik kesulitan dalam menyelesaikan soal-soal pemecahan masalah dan menerjemahkan soal kehidupan sehari-hari ke dalam model matematika (Agustyaningrum, 2011). Rendahnya kemampuan komunikasi matematis disebabkan oleh proses pembelajaran di dalam kelas. Pendidik masih menggunakan metode ceramah untuk menyampaikan materi sehingga peserta didik menjadi pasif karena pembelajaran berpusat pada pendidik. Akibatnya saat pendidik memberikan soal cerita, peserta didik mengalami kesulitan mengerjakannya. Karena peserta didik hanya mendengarkan setiap materi yang disampaikan oleh pendidik. Selain itu, peserta didik tidak mempunyai keberanian untuk bertanya kepada pendidik. Sehingga saat peserta didik sudah menemukan jawabannya, peserta didik masih merasa kebingungan dengan jawaban mereka dan merasa ragu-ragu untuk menjawab soal selanjutnya. Peserta didik juga masih kesulitan dalam mengubah soal cerita menjadi model matematika.

Model matematika adalah suatu cara sederhana untuk menerjemahkan suatu masalah ke dalam bahasa matematika dengan menggunakan persamaan, pertidaksamaan, atau fungsi (ES, 2008:39). Pemodelan matematika juga dapat disebut sebagai hasil dari penyelesaian masalah dalam kehidupan sehari-hari yang diselesaikan dengan cara matematika. Masalah dalam kehidupan sehari-hari dapat kita jumpai pada penerapan konsep matematika, misalnya penerapan sistem persamaan linear dua variabel. Sistem persamaan linear dua variabel (SPLDV) adalah sistem yang memiliki dua persamaan matematik dengan dua jenis variabel dan memiliki himpunan penyelesaian yang memenuhi kedua persamaan linear dua variabel (Agus, 2008:87). Soal dalam SPLDV cenderung berbentuk soal cerita dalam kehidupan sehari-hari. Kalimat dalam soal cerita diterjemahkan ke dalam model matematika sehingga peserta didik dapat dengan mudah menyelesaikan permasalahan tersebut. Tetapi, fakta yang sebenarnya menunjukkan bahwa peserta didik akan merasa kesulitan dalam mengerjakan soal cerita. Karena kemampuan mereka dalam mengubah soal cerita menjadi model matematika sangatlah rendah. Oleh karena itu, kemampuan komunikasi sangat penting dimiliki oleh setiap peserta didik. Jika peserta didik mempunyai kemampuan komunikasi matematika yang tinggi, maka siswa akan mudah mengubah soal cerita menjadi model matematika. Sehingga peserta didik dapat dengan mudah menyelesaikan suatu permasalahan yang diberikan oleh pendidik.

Berdasarkan penjelasan permasalahan tersebut, peneliti tertarik untuk mengkaji tentang kemampuan komunikasi matematika. Pada mulanya peneliti akan mengkategorikan kemampuan siswa berdasarkan hasil tes. Hasil tes peserta didik akan diranking menjadi tiga yaitu ranking tinggi, sedang, maupun rendah. Peneliti akan menganalisis bagaimana kemampuan komunikasi matematis siswa berdasarkan ranking yang sudah ditentukan. Sehingga tujuan dari penelitian ini adalah (1) Mendeskripsikan kemampuan komunikasi matematis siswa berkemampuan tinggi di kelas VIII MTs Darussalam Kademangan Blitar. (2) Mendeskripsikan kemampuan komunikasi matematis siswa berkemampuan 
sedang di kelas VIII MTs Darussalam Kademangan Blitar. (3) Mendeskripsikan kemampuan komunikasi matematis siswa berkemampuan rendah di kelas VIII MTs Darussalam Kademangan Blitar.

\section{METODE}

Pendekatan yang peneliti gunakan dalam penelitian ini adalah pendekatan kualitatif dengan jenis penelitiannya yaitu penelitian deskriptif. Penelitian kualitatif adalah penelitian yang menghasilkan data deskriptif berupa kata-kata tertulis atau lisan dari orang-orang dan perilaku yang diamati. (Moleong, 2005:6). Lokasi penelitian akan dilaksanakan di MTs Darussalam Kademangan Blitar yang terletak di Kecamatan Kademangan Kabupaten Blitar. Penelitian akan dilaksanakan di kelas VIII C yang terdiri dari 22 siswa yang kemudian akan diambil 6 subjek penelitian. Alasan mengapa peneliti melaksanakan penelitian di kelas VIII C adalah sebelumnya peneliti sudah berdiskusi dengan guru mata pelajaran matematika kelas VIII. Guru mata pelajaran matematika menganjurkan peneliti untuk melakukan penelitian di kelas VIII C. Teknik pengumpulan data dalam penelitian ini menggunakan data tes, wawancara, dan dokumentasi berupa foto. Analisis data dilakukan dengan langkah reduksi data, penyajian data dan penarikan kesimpulan (Miles, Hubberman \& Saldana, 2014)

\section{HASIL}

Penelitian dilaksanakan di MTs Darussalam Kademangan Blitar, tepatnya di kelas VIII C dengan materi Sistem Persamaan Linear Dua Variabel (SPLDV) yang telah diajarkan pada semester ganjil. Pada hari Rabu, 25 Januari 2017 peneliti memberikan tes materi SPLDV kepada siswa kelas VIII C. Tetapi sebelum pemberian tes dilaksanakan, peneliti menjelaskan kembali materi SPLDV agar siswa dapat mengingat kembali materi tersebut. Pemberian materi dilaksanakan pada jam ke-4 yaitu pukul 08.30 - 09.10. Selama pemberian materi, siswa kelas VIII C banyak yang lupa tentang materi SPLDV. Sehingga peneliti harus mengingatkan kembali materi tersebut sampai siswa kelas VIII C benarbenar mengingatnya. Setelah satu jam pelajaran selesai, peneliti tidak langsung memberikan tes kepada siswa karena setelah jam ke-4 adalah jam istirahat. Sehingga peneliti memberikan tes kepada siswa setelah jam istirahat yaitu jam ke5. Pada pukul 09.40 jam pelajaran masuk pada jam ke-5. Peneliti langsung memberikan tes kepada siswa dan dibantu oleh teman sejawat. Kehadiran teman sejawat selain menemani peneliti dalam penelitian juga membantu peneliti untuk dokumentasi. Peneliti melakukan pengamatan pada saat siswa kelas VIII C mengerjakan tes selama 2 jam pelajaran. Setelah 2 jam pelajaran selesai yaitu pukul 11.00, semua siswa mengumpulkan lembar jawaban. Peneliti mengakhiri pertemuan dengan salam dan memberitahukan kepada semua siswa jika akan diadakan wawancara. Wawancara diadakan pada hari Jumat tanggal 27 Januari 2017 dengan siswa yang menjadi subjek wawancara berjumlah 6 siswa. Pengumuman subjek yang akan diwawancarai diumumkan pada hari Kamis tanggal 26 Januari 2017.

Hari Kamis tanggal 26 Januari 2017, peneliti datang lagi ke MTs Darussalam untuk memberikan pengumuman siswa yang dijadikan subjek wawancara. Siswa yang dijadikan subjek wawancara berjumlah 6 siswa yang 
terdiri dari 2 siswa dengan nilai tinggi, 2 siswa dengan nilai sedang, dan 2 siswa dengan nilai rendah. Wawancara dilaksanakan pada hari Jumat tanggal 27 Januari 2017. Proses wawancara dilaksanakan di luar jam pelajaran. Wawancara dimulai sekitar pukul 11.00. Proses wawancara berjalan dengan lancar. Selama proses wawancara, peneliti ditemani oleh teman sejawat. Kehadiran teman sejawat membantu peneliti untuk keabsahan data, selain itu kehadiran teman sejawat dapat membantu peneliti pada waktu dokumentasi.

Penelitian yang peneliti lakukan sudah selesai, kemudian peneliti menganalisa data yang peneliti dapatkan di lapangan. Peneliti melakukan penginisialan kepada setiap siswa untuk mempermudah dalam analisa data. Selain itu, penginisialan dilakukan untuk menjaga privasi subjek penelitian. Penginisialan siswa dalam penelitian ini didasarkan pada inisial nama siswa. Misalnya, inisial FNK. Inisial FNK merupakan singkatan dari siswa dengan nama Faudjiah Nur Khaini. Daftar inisial siswa kelas VIII C yang mengikuti tes kemampuan komunikasi matematika secara lengkap dapat dilihat pada tabel $4.1 \mathrm{di}$ bawah ini.

\section{Tabel 1 Daftar Nama Siswa Kelas VIII C MTs Darussalam Kademangan Blitar yang Mengikuti Tes Kemampuan Komunikasi Matematis}

\begin{tabular}{|c|c|c|}
\hline NO. & INISIAL & L/P \\
\hline 1. & ATS & $\mathrm{P}$ \\
\hline 2. & ANL & $\mathrm{P}$ \\
\hline 3. & DAN & $\mathrm{P}$ \\
\hline 4. & DSA & $\mathrm{P}$ \\
\hline 5. & DSI & $\mathrm{P}$ \\
\hline 6. & DNL & $\mathrm{P}$ \\
\hline 7. & DRN & $\mathrm{P}$ \\
\hline 8. & EWI & $\mathrm{P}$ \\
\hline 9. & HMK & $\mathrm{P}$ \\
\hline 10. & IMH & $\mathrm{P}$ \\
\hline 11. & IAI & $\mathrm{P}$ \\
\hline 12. & ICS & $\mathrm{P}$ \\
\hline 13. & KDN & $\mathrm{P}$ \\
\hline 14. & KYS & $\mathrm{P}$ \\
\hline 15. & LSI & $\mathrm{P}$ \\
\hline 16. & LKJ & $\mathrm{P}$ \\
\hline 17. & LPI & $\mathrm{P}$ \\
\hline 18. & NRY & $\mathrm{P}$ \\
\hline 19. & NDN & $\mathrm{P}$ \\
\hline 20. & NKH & $\mathrm{P}$ \\
\hline 21. & SUH & $\mathrm{P}$ \\
\hline 22. & YMA & $\mathrm{P}$ \\
\hline
\end{tabular}

Siswa kelas VIII C berjumlah 22 siswa dan dari 22 siswa tersebut semua mengikuti tes kemampuan komunikasi matematis siswa dengan materi yang digunakan adalah Sistem Persamaan Linear Dua Variabel (SPLDV). Peneliti memilih materi ini karena dalam penyelesaiannya terdapat model matematika yang harus siswa tentukan dahulu melalui soal cerita yang sudah peneliti siapkan. 
Sehingga dengan begitu peneliti dapat menganalisis bagaimana kemampuan komunikasi matematis siswa mengubah soal cerita menjadi model matematika materi SPLDV. Instrumen dalam penelitian ini menggunakan tes dan wawancara. Soal tes dan pedoman wawancara terlebih dahulu divalidasi oleh ahli. Penilaian validasi dari dua dosen IAIN Tulungagung yaitu Dr. Muniri, M.Pd. dan Dr. Eny Setyowati, S.Pd. MM. serta guru dari MTs. Darussalam yaitu Ibu Anna Rifatul Hanifah, S.Pd.Si. Berdasarkan penilaian dari validator tersebut, diperoleh bahwa instrumen penelitian sudah valid dengan rata-rata total untuk instrumen tes yaitu sebesar 3,20. Sedangkan untuk instrumen wawancara yaitu sebesar 3,28. Sehingga, instrumen penelitian sudah valid dan layak untuk digunakan.

Tes yang peneliti berikan terdiri dari 3 soal dan dilaksanakan dengan rentang waktu 2 jam pelajaran yaitu 80 menit. Kegiatan ini berjalan dengan lancar. Selanjutnya dari 22 siswa dipilih 6 subjek untuk mengikuti wawancara. Siswa yang terpilih berdasarkan hasil dari tes. Wawancara dilakukan pada hari Jumat tanggal 27 Januari 2017. Wawancara digunakan untuk mengetahui bagaimana strategi siswa dalam mengubah soal cerita menjadi model matematika dan penyelesaiannya. Selama proses wawancara berlangsung, peneliti mencatat jawaban dari subjek penelitian agar memudahkan peneliti dalam memahami dan menganalisa data. Selain itu, peneliti juga menggunakan dokumentasi berupa foto.

\section{Tes kemampuan komunikasi matematis}

Hari Rabu, 25 Januari 2017 peneliti memberikan tes kemampuan komunikasi matematis dengan materi Sistem Persamaan Linear Dua Variabel (SPLDV). Pengerjaan tes dilakukan pada jam pelajaran ke-5 dan ke-6 pukul 09.40 - 11.00. Jumlah siswa kelas VIII C berjumlah 22 siswa dan pada hari Rabu 25 Januari 2017 semua siswa mengikuti tes. Pemberian tes digunakan peneliti untuk mengetahui bagaimana strategi siswa dalam mengubah soal cerita menjadi model matematika dan penyelesaiannya. Hasil dari tes digunakan peneliti untuk memilih subjek yang akan diwawancarai. Pemilihan subjek wawancara dilakukan dengan cara pengelompokan kelas berdasarkan 3 ranking. Cara tersebut memudahkan peneliti untuk mengkategorikan siswa kelas VIII C menjadi 3 kategori yaitu kategori tinggi, sedang, dan rendah dengan interval pengkategorian adalah sebagai berikut: (1) Siswa masuk kategori tinggi jika nilai siswa tersebut berada dalam interval nilai $\geq 82$. (2) Siswa masuk kategori sedang jika nilai siswa tersebut berada dalam interval $47<$ nilai $<82$. (b) Siswa masuk kategori rendah jika nilai siswa tersebut berada dalam interval nilai $\leq 47$. Berikut merupakan hasil dari tes kemampuan komunikasi matematika siswa kelas VIII C beserta pengkategoriannya.

Tabel 2 Hasil Tes Kemampuan Komunikasi Matematis Siswa Kelas VIII C

\begin{tabular}{|c|c|c|c|}
\hline NO. & INISIAL & HASIL TES & KATEGORI TES \\
\hline 1. & ATS & 45 & Rendah \\
\hline 2. & ANL & 45 & Rendah \\
\hline 3. & DAN & 55 & Sedang \\
\hline 4. & DSA & 55 & Sedang \\
\hline 5. & DSI & 85 & Tinggi \\
\hline 6. & DNL & 50 & Sedang \\
\hline 7. & DRN & 55 & Sedang \\
\hline
\end{tabular}




\begin{tabular}{|c|c|c|c|}
\hline 8. & EWI & 35 & Rendah \\
\hline 9. & HMK & 55 & Sedang \\
\hline 10. & IMH & 85 & Tinggi \\
\hline 11. & IAI & 55 & Sedang \\
\hline 12. & ICS & 85 & Tinggi \\
\hline 13. & KDN & 85 & Tinggi \\
\hline
\end{tabular}

Berdasarkan hasil tes dan penginisialan di atas, peneliti mengambil 6 subjek secara acak dengan syarat 2 siswa dengan kategori tinggi, 2 siswa dengan kategori sedang, dan 2 siswa dengan kategori rendah untuk diwawancarai. Daftar subjek wawancara secara lengkap dapat dilihat pada tabel berikut ini.

Tabel 3 Daftar Nama Siswa Kelas VIII C yang menjadi Subjek Wawancara

\begin{tabular}{|c|c|c|}
\hline NO. & KODE SISWA & KATEGORI TES \\
\hline 1. & KYS & Tinggi \\
\hline 2. & YMA & Tinggi \\
\hline 3. & NRY & Sedang \\
\hline 4. & DNL & Sedang \\
\hline 5. & ANL & Rendah \\
\hline 6. & EWI & Rendah \\
\hline
\end{tabular}

\section{PEMBAHASAN}

\section{Kemampuan Komunikasi Matematis Siswa pada Ranking Tinggi}

Berdasarkan data yang diperoleh dari hasil tes dan wawancara, siswa pada ranking tinggi mampu menggunakan variabel untuk memisalkan apa yang diketahui dalam soal cerita. Hal tersebut didukung dengan pernyataan dari Agustyaningrum (2011) bahwa aspek kemampuan komunikasi matematis yang akan diukur meliputi kemampuan dalam menggunakan istilah-istilah, simbolsimbol matematika, dan struktur-strukturnya untuk memodelkan situasi atau permasalahan matematika. Hal tersebut juga didukung dengan pernyataan dari Yosmarniati (2012:66) bahwa salah satu indikator kemampuan komunikasi matematis siswa yang harus dipenuhi yaitu siswa mampu menyatakan pernyataan matematika melalui gambar/model/simbol. Sedangkan indikator kemampuan komunikasi matematis secara tulisan yaitu: 1) siswa mampu menggambarkan situasi masalah dan menyatakan solusi masalah menggunakan gambar, bagan, tabel, atau penyajian secara aljabar, 2) siswa mampu membuat situasi matematika dengan menyediakan ide dan keterangan dalam bentuk tulisan, 3) siswa mampu menggunakan bahasa matematika dan simbol secara tepat (Jurotun, 2015).

Siswa pada ranking tinggi mampu mengubah bahasa matematika yang terdapat dalam soal cerita menjadi model matematika. Hal tersebut didukung dengan pernyataan dari Agustyaningrum (2011) yang mengemukakan bahwa aspek kemampuan komunikasi matematis yang akan diukur meliputi kemampuan dalam menggunakan istilah-istilah, simbol-simbol matematika, dan strukturstrukturnya untuk memodelkan situasi atau permasalahan matematika. Selain itu, hal tersebut juga didukung dengan pernyataan dari Yosmarniati (2012:66) mengemukakan bahwa indikator kemampuan komunikasi matematis siswa yang 
harus dipenuhi yaitu siswa mampu menyatakan pernyataan matematika melalui gambar/simbol/model matematika dan siswa mampu merumuskan generalisasi.

Siswa pada ranking tinggi mampu merumuskan apa yang diketahui dengan pemisalan menggunakan variabel. Kemudian dengan bantuan variabel tersebut, siswa mampu membuat model matematika yang dapat mempermudah siswa untuk menyelesaikan soal cerita tersebut. Jurotun (2015) juga mendukung pernyataan tersebut dengan mengemukakan indikator kemampuan komunikasi matematis secara lisan dan tulisan. Indikator kemampuan komunikasi matematis siswa secara lisan yaitu siswa mampu menggunakan tabel, gambar, model, dan lain-lain untuk menyampaikan penjelasan. Sedangkan indikator kemampuan komunikasi matematis secara tulisan yaitu: (1) siswa mampu menggambarkan situasi masalah dan menyatakan solusi masalah menggunakan gambar, bagan, tabel, atau penyajian secara aljabar, (2) siswa mampu menggunakan representasi menyeluruh untuk menyatakan konsep matematika dan solusinya, (3) siswa mampu menggunakan bahasa matematika dan simbol secara tepat.

\section{Kemampuan Komunikasi Matematis Siswa pada Ranking Sedang}

Berdasarkan data yang diperoleh dari hasil tes dan wawancara, siswa pada ranking sedang mampu menggunakan variabel untuk memisalkan apa yang diketahui dalam soal cerita. Hal tersebut didukung dengan pernyataan dari Agustyaningrum (2011) yang mengemukakan bahwa aspek kemampuan komunikasi matematis yang akan diukur meliputi kemampuan dalam menggunakan istilah-istilah, simbol-simbol matematika, dan struktur-strukturnya untuk memodelkan situasi atau permasalahan matematika. Selain itu, hal tersebut juga didukung dengan pernyataan Yosmarniati (2012:66) yang mengemukakan bahwa salah satu indikator kemampuan komunikasi matematis siswa yang harus dipenuhi yaitu siswa mampu menyatakan pernyataan matematika melalui gambar /simbol/model matematika.

Jurotun (2015) juga mendukung pernyataan tersebut dengan mengemukakan indikator kemampuan komunikasi matematis secara lisan dan tulisan. Indikator kemampuan komunikasi matematis siswa secara lisan yaitu siswa mampu mengungkapkan lambang, notasi, dan persamaan matematika secara lengkap dan benar. Sedangkan indikator kemampuan komunikasi matematis secara tulisan yaitu: (1) siswa mampu menggambarkan situasi masalah dan menyatakan solusi masalah menggunakan gambar, bagan, tabel, atau penyajian secara aljabar, (2) siswa mampu membuat situasi matematika dengan menyediakan ide dan keterangan dalam bentuk tulisan, (3) siswa mampu menggunakan bahasa matematika dan simbol secara tepat (Jurotun, 2015).

Siswa pada ranking sedang mampu mengubah bahasa matematika yang terdapat dalam soal cerita menjadi model matematika. Hal tersebut didukung dengan pernyataan Agustyaningrum (2011) yang mengemukakan bahwa aspek kemampuan komunikasi matematis yang akan diukur meliputi kemampuan dalam menggunakan istilah-istilah, simbol-simbol matematika, dan struktur-strukturnya untuk memodelkan situasi atau permasalahan matematika. Selain itu, hal tersebut juga didukung dengan pernyataan dari Yosmarniati (2012:66) yang mengemukakan bahwa indikator kemampuan komunikasi matematis siswa yang harus dipenuhi yaitu siswa mampu menyatakan pernyataan matematika melalui gambar/simbol/model matematika dan siswa mampu merumuskan generalisasi. 
Siswa pada ranking sedang mampu merumuskan apa yang diketahui dengan pemisalan menggunakan variabel. Kemudian dengan bantuan variabel tersebut, siswa mampu membuat model matematika yang dapat mempermudah siswa untuk menyelesaikan soal cerita tersebut. Jurotun (2015) juga mendukung pernyataan tersebut dengan mengemukakan indikator kemampuan komunikasi matematis secara lisan dan tulisan. Indikator kemampuan komunikasi matematis siswa secara lisan yaitu siswa mampu menggunakan tabel, gambar, model, dan lain-lain untuk menyampaikan penjelasan. Sedangkan indikator kemampuan komunikasi matematis secara tulisan yaitu: 1) siswa mampu menggambarkan situasi masalah dan menyatakan solusi masalah menggunakan gambar, bagan, tabel, atau penyajian secara aljabar, 2) siswa mampu menggunakan representasi menyeluruh untuk menyatakan konsep matematika dan solusinya, 3) siswa mampu menggunakan bahasa matematika dan simbol secara tepat Jurotun (2015).

\section{Kemampuan Komunikasi Matematis Siswa pada Ranking Rendah}

Berdasarkan data yang diperoleh dari hasil tes dan wawancara, siswa pada ranking rendah belum mampu menggunakan variabel untuk memisalkan apa yang diketahui dalam soal cerita. Hal tersebut berbeda dengan pernyataan dari Agustyaningrum (2011) yang mengemukakan bahwa aspek kemampuan komunikasi matematis yang akan diukur meliputi kemampuan dalam menggunakan istilah-istilah, simbol-simbol matematika, dan struktur-strukturnya untuk memodelkan situasi atau permasalahan matematika. Selain itu, hal tersebut juga berbeda dengan pernyataan Yosmarniati (2012:66) yang mengemukakan bahwa salah satu indikator kemampuan komunikasi matematis siswa yang harus dipenuhi yaitu siswa mampu menyatakan pernyataan matematika melalui gambar /simbol/model matematika.

Jurotun (2015) mengemukakan indikator kemampuan komunikasi matematis secara lisan dan tulisan. Indikator kemampuan komunikasi matematis siswa secara lisan yaitu siswa mampu mengungkapkan lambang, notasi, dan persamaan matematika secara lengkap dan benar. Sedangkan indikator kemampuan komunikasi matematis secara tulisan yaitu: 1) siswa mampu menggambarkan situasi masalah dan menyatakan solusi masalah menggunakan gambar, bagan, tabel, atau penyajian secara aljabar, 2) siswa mampu membuat situasi matematika dengan menyediakan ide dan keterangan dalam bentuk tulisan, 3) siswa mampu menggunakan bahasa matematika dan simbol secara tepat Jurotun (2015). Pernyataan dari Jurrotun berbeda dengan kemampuan komunikasi matematis pada siswa ranking rendah.

Siswa pada ranking rendah belum mampu mengubah bahasa matematika yang terdapat dalam soal cerita menjadi model matematika. Hal tersebut berbeda dengan pernyataan Agustyaningrum (2011) yang mengemukakan bahwa aspek kemampuan komunikasi matematis yang akan diukur meliputi kemampuan dalam menggunakan istilah-istilah, simbol-simbol matematika, dan struktur-strukturnya untuk memodelkan situasi atau permasalahan matematika. Selain itu, pernyataan tersebut juga berbeda dengan pernyataan Yosmarniati (2012:66) yang mengemukakan bahwa indikator kemampuan komunikasi matematis siswa yang harus dipenuhi yaitu siswa mampu menyatakan pernyataan matematika melalui gambar/simbol/model matematika dan siswa mampu merumuskan generalisasi.

467 BRILIANT: Jurnal Riset dan Konseptual Volume 2 Nomor 4, November 2017 
Siswa pada ranking rendah belum mampu merumuskan apa yang diketahui dengan pemisalan menggunakan variabel. Sehingga siswa mampu belum mampu membuat model matematika. Jurotun (2015) mengemukakan indikator kemampuan komunikasi matematis secara lisan dan tulisan. Indikator kemampuan komunikasi matematis siswa secara lisan yaitu siswa mampu menggunakan tabel, gambar, model, dan lain-lain untuk menyampaikan penjelasan. Sedangkan indikator kemampuan komunikasi matematis secara tulisan yaitu: 1) siswa mampu menggambarkan situasi masalah dan menyatakan solusi masalah menggunakan gambar, bagan, tabel, atau penyajian secara aljabar, 2) siswa mampu menggunakan representasi menyeluruh untuk menyatakan konsep matematika dan solusinya, 3) siswa mampu menggunakan bahasa matematika dan simbol secara tepat Jurotun (2015). Pernyataan dari Jurrotun berbeda dengan kemampuan komunikasi matematis pada siswa ranking rendah.

\section{KESIMPULAN}

Pada kemampuan komunikasi matematis siswa pada ranking tinggi siswa mampu menggunakan variabel untuk memisalkan apa yang diketahui dalam soal cerita. Siswa mampu mengubah bahasa matematika yang terdapat dalam soal cerita menjadi model matematika. Siswa mampu merefleksikan bahasa matematika yang terdapat dalam soal cerita. Siswa mampu menyelesaikan soal dengan lengkap dan benar. Siswa mampu menjawab pertanyaan peneliti dengan lugas mengenai bagaimana siswa mengubah soal cerita menjadi model matematika dan strategi penyelesaiannya. Pada kemampuan komunikasi matematis siswa pada ranking sedang. Siswa mampu menggunakan variabel untuk memisalkan apa yang diketahui dalam soal cerita. Siswa mampu mengubah bahasa matematika yang terdapat dalam soal cerita menjadi model matematika. Siswa belum mampu merefleksikan bahasa matematika yang terdapat dalam soal cerita. Siswa belum mampu menyelesaikan soal dengan lengkap dan benar. Siswa belum mampu menjawab pertanyaan peneliti dengan lugas mengenai bagaimana siswa mengubah soal cerita menjadi model matematika dan strategi penyelesaiannya. Pada kemampuan komunikasi matematis siswa pada ranking rendah. Siswa belum mampu menggunakan variabel untuk memisalkan apa yang diketahui dalam soal cerita. Siswa belum mampu mengubah bahasa matematika yang terdapat dalam soal cerita menjadi model matematika. Siswa belum mampu merefleksikan bahasa matematika yang terdapat dalam soal cerita. Siswa belum mampu menyelesaikan soal dengan lengkap dan benar. Siswa belum mampu menjawab pertanyaan peneliti dengan lugas mengenai bagaimana siswa mengubah soal cerita menjadi model matematika dan strategi penyelesaiannya.

\section{SARAN}

Bagi Sekolah, sebaiknya pihak sekolah memajukan mutu mata pelajaran terutama pelajaran matematika. Selain itu, pihak sekolah sebaiknya lebih memperhatikan pentingnya kemampuan komunikasi matematis agar siswa mampu menyampaikan ide, gagasan, atau mengekspresikan bahasa matematika. Bagi guru mata pelajaran matematika, sebaiknya guru lebih memperhatikan perkembangan kemampuan siswa terutama kemampuan komunikasi matematis siswa ketika siswa menyelesaikan permasalahan yang guru berikan. Selain itu, guru sebaiknya sering melatih siswa untuk menyelesaikan soal-soal dalam bentuk soal cerita. 
Serta sebaiknya guru mampu membantu siswa jika siswa mengalami kesulitan dalam menerjemahkan soal cerita menjadi model matematika.

\section{DAFTAR RUJUKAN}

Ag, Moch. Masykur \& Abdul Halim Fathani. 2008. Mathematical Intelligence: Cara Cerdas Melatih Otak dan Menanggulangi Kesulitan Belajar. Yogyakarta: Ar-Ruzz Media.

Agus, Nuniek Avianti. 2008. Mudah Belajar Matematika 2: untuk kelas VIII Sekolah Menengah Pertama/Madrasah Tsanawiyah. Jakarta: Pusat Perbukuan Departemen Pendidikan Nasional.

Agustyaningrum, Nina. 2011. Implementasi Model Pembelajaran Learning Cycle 5E Untuk Meningkatkan Kemampuan Komunikasi Matematis Siswa Kelas IX B SMP Negeri 2 Sleman, Seminar Nasional Matematika dan Pendidikan Matematika. Yogyakarta: UNY.

Anisa, Witri Nur. 2014. Peningkatan Kemampuan Pemecahan Masalah Dan Komunikasi Matematik Melalui Pembelajaran Pendidikan Matematika Realistik Untuk Siswa SMP Negeri Di Kabupaten Garut. Jurnal Pendidikan dan Keguruan. 1(1).

E.S., Pesta. 2008. Matematika Aplikasi. Jakarta: Pusat Perbukuan Departemen Pendidikan Nasional.

Effendy, Onong Uchjana. 2004. Dinamika Komunikasi. Bandung: PT. Remaja Rosdakarya.

Departemen Agama RI. tt. Al-Qur'an dan Terjemahannya. Indonesia: PT. Syaamil Cipta Media.

Jurotun. 2015. Meningkatkan Komunikasi Matematis Peserta Didik melalui "Disco Lemper" Berbantuan Software Geogebra. Kreano. 6(1).

Lanani, Karman. 2013. Belajar Berkomunikasi dan Komunikasi untuk Belajar dalam Pembelajaran Matematika, Jurnal Ilmiah Program Studi Matematika STKIP Siliwangi Bandung, 2(1).

Miles, M.B., Huberman, A.M., \& Saldana, J. 2014. Qualitative Data Analysis: A Methods Sourcebook. Third Edition. SAGE Publication Asia-Pacific Pte. Ltd. Singapore.

Moleong, Lexy J. 2015. Metodologi Penelitian Kualitatif. Bandung: PT Remaja Rosdakarya.

Muzayanah, Iim \& Puji Nugraheni. Penerapan Pembelajaran The Power Of Two Untuk Meningkatkan Komunikasi Dan Hasil Belajar Matematika. Jurnal Program Studi Pendidikan Matematika FKIP Universitas Muhammadiyah Purworejo.

Yosmarniati, dkk. 2012. Upaya Meningkatkan Kemampuan Komunikasi Matematika Siswa Melalui Pendekatan Pendidikan Matematika Realistik. Jurnal Pendidikan Matematika. 1(1).

Yunianto, Rosid \& Jailani. 2014. Keefektifan CTL Menggunakan Model STAD dan GI Ditinjau dari Prestasi, Komunikasi, dan Sikap terhadap Matematika. Jurnal Pendidikan Matematika. 9(1). 